\title{
Trends in Mean Annual Streamflows in Serra da Mantiqueira Environmental Protection Area
}

\author{
Mateus Ricardo Nogueira Vilanova* \\ Programa de Pós-graduação em Engenharia Mecânica (Transmissão e Conversão de Energia); Departamento de \\ Engenharia Civil; Faculdade de Engenharia de Guaratinguetá; Universidade Estadual Paulista; Guaratinguetá - \\ SP - Brasil
}

\begin{abstract}
The aim of this study was to detect trends in the mean annual streamflow in watersheds of Serra da Mantiqueira Environmental Protection Area, an important Brazilian conservation area located between Minas Gerais, São Paulo and Rio de Janeiro States. Historical series of four selected streamgage stations were analyzed for the periods of 1980-1998 and 1980-2009, using the Mann-Kendall and Regional Mann-Kendall tests. The results showed that the mean annual streamflows of Serra da Mantiqueira Environmental Protection Area watersheds did not change during the complete period of 1980-2009. The tests detected statistically significant trends of reduction of mean annual streamflow during the 1980-1998 period. The confrontation of this result with the inexistence of rainfall trends during the same period suggested that the streamflow changes detected were consequences of changes in the watersheds physical characteristics, and/or increases in water abstraction for multiple uses.
\end{abstract}

Key words: streamflow changes, Serra da Mantiqueira Range, Mann-Kendall test

\section{INTRODUCTION}

Streamflow is one of the most studied hydrological variables, given its importance for humanity and ecosystems. Various water uses are highly dependent on their spatial-temporal patterns, since surface water is the easiest and more accessible source that can be used for human and animal consumption, irrigation and other uses. In environmental and ecological terms, streams and rivers are, by themselves, singular aquatic ecosystems influenced by the variability of the streamflow, which changes the hydrodynamic and biochemical characteristics of the aquatic environment.

The understanding and detection of changes of streamflow patterns is essential for water resources and environmental planning and management. The main drivers of these changes are the dynamics of land use and occupation in watersheds, the climate changes, the evolution of water uses, or a combination of these factors. The climate prediction models considered by the International Panel for Climate Change (Bates et al. 2008) allows to estimate the changes in streamflow due to global warming projections in different regions of the world. Complementarily, studies of streamflow trends in smaller spatial scales mainly in the watershed scale - are valuable for environmental and water resources planning and management applications ( He et al. 2013, Joseph et al. 2013 Harrigan et al. 2014).

The Serra da Mantiqueira (SM) is a major Brazilian relief unit located between the States of São Paulo (SP), Minas Gerais (MG) and Rio de Janeiro (RJ), with great relevance in terms of water resources, environment and human development. The SM environmental importance

*Author for correspondence: mathidr@yahoo.com.br 
was highlighted by Becker et al. (2013), who pointed its condition of Atlantic Forest Biodiversity Hotspot and wildlife corridor. The Serra da Mantiqueira Environmental Protection Area (SMEPA) was created in 1985 through Brazilian Decree 91.304 (Brasil 1985), occupying an area of $4,218 \mathrm{~km}^{2}$, and located along the topographical divisor of two major Brazilian basins, the Paraíba do Sul River Basin (BRPS) and the Grande River Basin (BRG). Several multiple uses of water in these two basins depend on water sources whose springs are within the SM limits.

Given the relevance of hydrological trends studies and the importance of Serra da Mantiqueira in the Brazilian water resources, environment and development scenarios, this work aimed to detect monotonic trends in time series of mean annual streamflow of watersheds located entirely or mostly within the SMEPA. Specific objectives were: (1) detect trends in the mean annual streamflow in single watersheds, (2) detect trends in regional mean annual streamflow and (3) compare the detected streamflow trends with rainfall trends of selected rain gages, to deduce if streamflow trends were due to climate changes or human activities. The results of the study would allow to conclude if the mean annual streamflow in watercourses of SMEPA were decreasing or increasing, which could be an important contribution to regional and national water resources planning and management initiatives.

\section{MATERIALS AND METHODS}

\section{Area of study}

The study area is located in Southeast Region of Brazil and corresponds spatially to SMEPA. More specifically, watersheds whose area and springs are located mostly within the SMEPA were considered. Figure 1 shows the location of SMEPA in Brazil and in relation to the SP, MG and RJ States and BRPS and BRG.

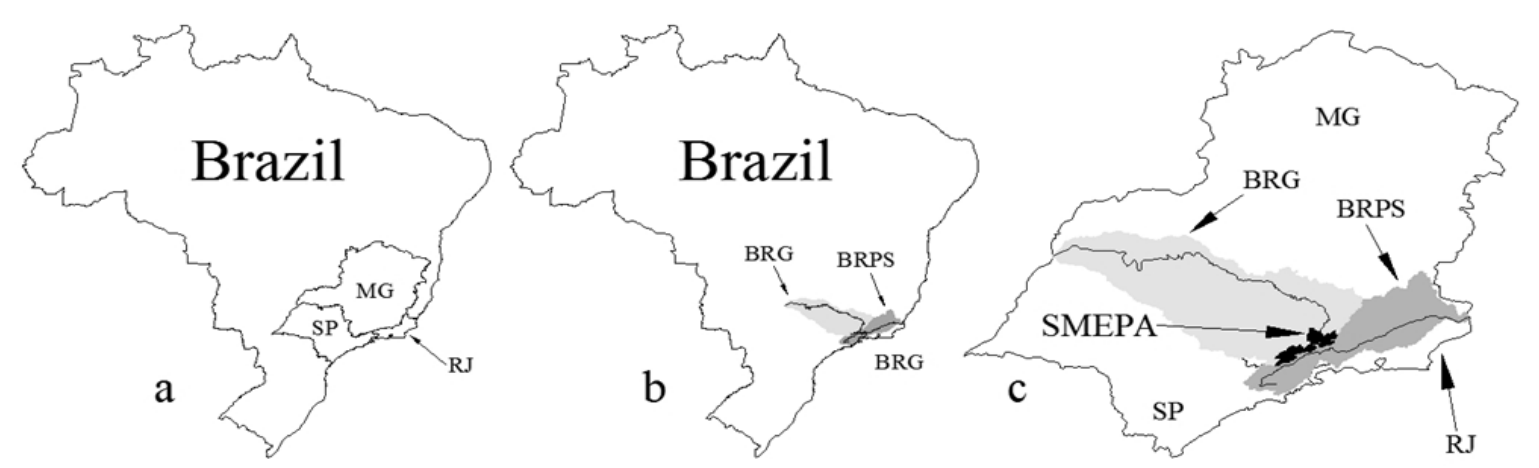

Figure 1 - Location of the study area. Figure 1a shows the political division of MG, SP and RJ States. Figure 1b shows the Grande River Basin (BRG, in light gray) and Paraíba do Sul River Basin (BRPS, in dark gray). Figure 1c shows the location of the Serra da Mantiqueira Environmental Protection Area (SMEPA) in relation to the States and basins.

\section{Streamflow and rainfall stations and data}

The database used in the study was the HIDROWEB (http://hidroweb.ana.gov.br/), maintained by the Brazilian National Water Agency (ANA). Complementary series were obtained from the database maintained by the São Paulo State Integrated Water Resources Management System (http://www.sigrh.sp.gov.br/ cgi-bin/bdhm.exe/flu?lig=podfp). Thirty-five streamgage stations were initially identified in watercourses of Serra da Mantiqueira (15 from BRPS and 20 from BRG). Despite the significant number of stations identified, some drawbacks made many of them unsuitable for use in the analysis, such as short period time series, significant data gaps (thus, only the stations whose mean daily streamflow series was at least $95 \%$ integrity during the periods considered were used here), outdated series, lack of coincidence between the series in most recent periods, and redundant stations in same streams (thus, only the stations located further upstream in the watercourse, which implied their placement within or near the SMEPA were used in this study). Some stations presented data gaps in coincident periods, which prevented its use for mutual data fulfillment. After analyzing 
these factors, two periods were defined for the trend analysis and the stations to be used:

between 1980 and 1998 (18 years), a period with complete series of four stations (two from BRPS and two from BRG);

between 1980 and 2009 (29 years), a most recent period, with complete series of two stations (one from BRPS and one from BRG).

The mean annual streamflows were calculated from the mean daily streamflow series, considering the normal climatological/ hydrological year of Brazilian Southeast Region. It was assumed that the beginning of wet season occur with the beginning of spring (September 22). In practical terms, the beginning of the hydrological year was in the month of October; the mean annual streamflows were calculated from the mean daily streamflows from October of each year to September of the following year. The stations selected for this study and their location in relation to SMEPA are shown in Table 1 and Figure 2, respectively.

Table 2 presents the characteristic streamflows of the stations analyzed - the complete period mean streamflow (MSF), and the complete period specific streamflow (SMSF), calculated by the division of MSF by the station drainage area -, and the procedures used for data gaps fulfillment.

In addition to the streamflow analysis, rainfall time series from four selected stations of SMEPA were analyzed for detecting trends in the same periods of streamflow analysis. These series were obtained from the same database of streamflow series (Hidroweb) and was submitted to the same selection procedures described for streamflow data. The rainfall series of selected stations showed high data integrity; small gaps in the series were filled by linear regression between their total monthly rainfalls. These monthly total rainfalls were then used for the calculation of its total annual rainfall that were used in the trend analysis. Three of the selected rain gages were located in the same sites of the considered streamgages (called as "associated streamgages"); one of the rain gage stations, 2245087, was not associated with any streamgage, and was specially selected due its location in a central position in relation to the longitudinal extension of SMEPA, improving the spatial significance of the regional rainfall trend analysis. Table 3 presents the rain gage stations used in the study.

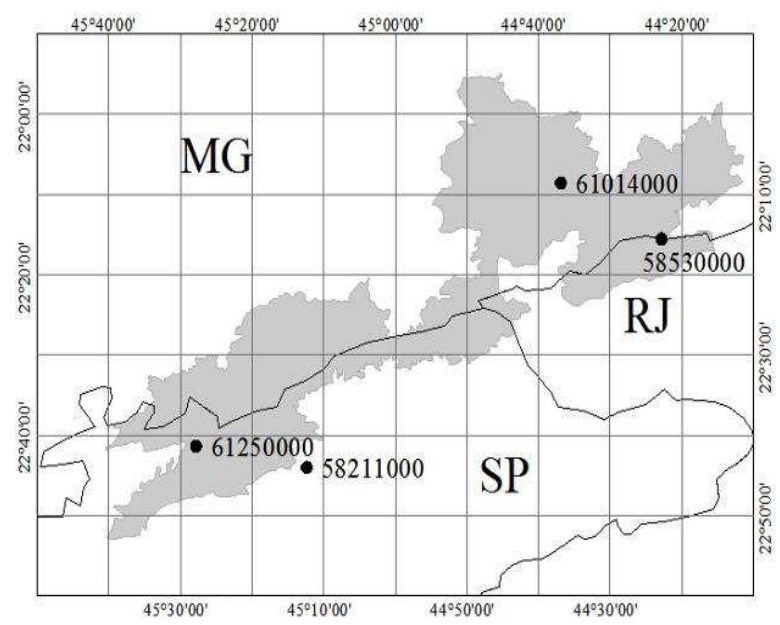

Figure 2 - Location of streamgage stations used in the study, in relation to SMEPA (in gray) and the States of MG, SP and RJ.

Table 1 - Streamflow stations used in trend analysis.

\begin{tabular}{|c|c|c|c|c|c|c|c|c|}
\hline \multirow{2}{*}{$\begin{array}{c}\text { ANA ID } \\
\text { (Operator) }\end{array}$} & \multirow{2}{*}{$\begin{array}{l}\text { Basin } \\
\text { River }\end{array}$} & \multirow{2}{*}{$\begin{array}{l}\text { Municipality } \\
\text { State }\end{array}$} & \multicolumn{2}{|c|}{ Geographic coordinates } & \multirow{2}{*}{$\begin{array}{c}\text { Altitude } \\
{[\mathrm{m}]}\end{array}$} & \multirow{2}{*}{$\begin{array}{c}\text { Drainage } \\
\text { area }\left[\mathbf{k m}^{2}\right]\end{array}$} & \multicolumn{2}{|c|}{ Data integrity } \\
\hline & & & Latitude & Longitude & & & 1980-1998 & 1980-2009 \\
\hline $\begin{array}{c}58211000 \\
\text { (FCTH-DAEE) }\end{array}$ & $\begin{array}{l}\text { BRPS } \\
\text { Piagui }\end{array}$ & $\begin{array}{c}\text { Guaratinguetá } \\
\text { SP }\end{array}$ & $-22^{\circ} 44^{\prime} 13^{\prime \prime}$ & $-45^{\circ} 12^{\prime} 11^{\prime \prime}$ & 523 & 171 & $\cong 100 \%$ & - \\
\hline $\begin{array}{c}58530000 \\
(\mathrm{CPRM})\end{array}$ & $\begin{array}{l}\text { BRPS } \\
\text { Preto }\end{array}$ & $\begin{array}{l}\text { Resende } \\
\text { RJ }\end{array}$ & $-22^{\circ} 16^{\prime} 14^{\prime \prime}$ & $-44^{\circ} 23^{\prime} 30^{\prime \prime}$ & 915 & 284 & $100 \%$ & $\cong 100 \%$ \\
\hline $\begin{array}{l}61014000 \\
(\text { IGAM })\end{array}$ & $\begin{array}{c}\text { BRG } \\
\text { Aiuruoca }\end{array}$ & $\begin{array}{l}\text { Alagoa } \\
\text { MG }\end{array}$ & $-22^{\circ} 10^{\prime} 12^{\prime}$ & $-44^{\circ} 38^{\prime} 13{ }^{\prime}$ & 1036 & 282 & $100 \%$ & $96 \%$ \\
\hline $\begin{array}{l}61250000 \\
(\text { IGAM })\end{array}$ & $\begin{array}{c}\text { BRG } \\
\text { Sapucaí }\end{array}$ & $\begin{array}{c}\text { Campos do Jordão } \\
\text { SP }\end{array}$ & $-22^{\circ} 41^{\prime} 16^{\prime \prime}$ & $-45^{\circ} 28^{\prime} 47^{\prime}$ & 1501 & 109 & $95 \%$ & - \\
\hline
\end{tabular}


Table 2 - Characteristic streamflows and data gaps fulfillment procedures employed in streamflow station's hystorical series.

\begin{tabular}{|c|c|c|c|c|c|}
\hline \multirow[b]{2}{*}{ ANA ID } & \multicolumn{2}{|c|}{ 1980-1998 } & \multicolumn{2}{|c|}{ 1980-2009 } & \multirow[b]{2}{*}{ Data gaps fulfillment procedures } \\
\hline & $\begin{array}{c}\text { MSF } \\
{\left[\mathrm{m}^{3} \cdot \mathrm{s}^{-1}\right]}\end{array}$ & $\begin{array}{c}\text { SMSF } \\
{\left[1 .\left(\mathbf{s . k m}^{2}\right)^{-1}\right]}\end{array}$ & $\begin{array}{c}\text { MSF } \\
{\left[\mathrm{m}^{3} \cdot \mathrm{s}^{-1}\right]}\end{array}$ & $\begin{array}{c}\text { SMSF } \\
{\left[1 .\left(\mathbf{s . k m}^{2}\right)^{-1}\right]}\end{array}$ & \\
\hline 58211000 & 5.23 & 30.58 & - & 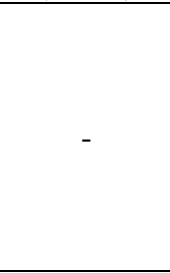 & $\begin{array}{l}\text { Due to (1) absence of water level measurement during the gaps } \\
\text { periods and consequent impossibility to fill the gaps through } \\
\text { stage-discharge relations and (2) absence of another station on } \\
\text { the same river, the data gap of April } 1986 \text { was filled with the } \\
\text { mean streamflow of the previous and following months (March } \\
1986 \text { and May 1986). This data gap represents } 0.46 \% \text { of the } \\
\text { length of the complete series. }\end{array}$ \\
\hline 58530000 & 12.46 & 43.87 & 12.76 & 44.93 & $\begin{array}{l}\text { The station's series presented only one data (one day mean } \\
\text { daily streamflow) missing. This was filled with the mean of the } \\
\text { mean daily streamflow of the previous and following days. }\end{array}$ \\
\hline 61014000 & 7.96 & 28.22 & 7.75 & 27.51 & $\begin{array}{l}\text { The station series gaps were initially filled by linear regression } \\
\text { between their mean daily streamflows and those from station } \\
61024000 \text {, located on the same watercourse. The months of } \\
\text { April 2002, December } 2002 \text {, May } 2007 \text { and December/2008 } \\
\text { were filled with respective mean streamflows of previous and } \\
\text { following months, because of (1) gaps in the same periods in } \\
\text { the series of station } 61024000 \text { and (2) the absence of water } \\
\text { level measurements for filling the gaps by the use of stage- } \\
\text { discharge relations. The gaps of months cited represent only } \\
1.15 \% \text { of the length of the series in the period } 1980-2009 \text {. }\end{array}$ \\
\hline 61250000 & 3.81 & 34.95 & - & - & $\begin{array}{l}\text { The series was completed by linear regression between their } \\
\text { mean daily streamflows and those from station } 61250100 \text {, } \\
\text { located on the same river. }\end{array}$ \\
\hline
\end{tabular}

Table 3 - Rainfall stations used in trend analysis.

\begin{tabular}{ccccccc}
\hline $\begin{array}{c}\text { ANA ID } \\
\text { (Operator) }\end{array}$ & $\begin{array}{c}\text { Associated } \\
\text { streamgage }\end{array}$ & $\begin{array}{c}\text { Municipality } \\
\text { State }\end{array}$ & \multicolumn{2}{c}{ Geographic coordinates } & Mean total annual rainfall [mm] \\
\cline { 3 - 6 } & Latitude & Longitude & $\mathbf{1 9 8 0 - 1 9 9 8}$ & $\mathbf{1 9 8 0 - 2 0 0 9}$ \\
\hline 2245010 & 61250000 & Campos do Jordão - SP & $-22^{\circ} 41^{\prime} 20^{\prime}{ }^{\prime}$ & $-45^{\circ} 28^{\prime} 53^{\prime \prime}$ & 1878 & 1836 \\
2245087 & - & Delfim Moreira - MG & $-22^{\circ} 24^{\prime} 25^{\prime}$, & $-45^{\circ} 12^{\prime} 54^{\prime}$, & 1554 & 1558 \\
2244065 & 61014000 & Alagoa - MG & $-22^{\circ} 10^{\prime} 12^{\prime}$, & $-44^{\circ} 38^{\prime} 13^{\prime}$, & 1809 & 1775 \\
2244038 & 58530000 & Resende - RJ & $-22^{\circ} 16^{\prime} 14^{\prime}$, & $-44^{\circ} 23^{\prime} 30^{\prime \prime}$ & 2146 & 2163 \\
\hline
\end{tabular}

\section{Mann-Kendall test}

The Mann-Kendall was developed by Mann (1945) and Kendall (1975). The test checks for the monotonic trends (increase or decrease) in time series (Hipel and Mcleod 1994), being a nonparametric and rank-based method $(\mathrm{Xu}$ et al. 2010), not requiring the assumption of normality (Helsel and Frans 2006). Equation (1) shows the Mann-Kendall test statistic, considering the null hypothesis $\left(\mathrm{H}_{\mathrm{o}}\right)$ that the data comes from a population whose random variables are independent and identically distributed, while the alternative hypothesis $\left(\mathrm{H}_{1}\right)$ represents the existence of a monotonic trend (Hipel and Mcleod 1994). In Equations 1 and 2, $\mathrm{S}$ is the Mann-Kendall test statistic, $\mathrm{n}$ is the size of the sample (number of mean annual streamflows in the period of analysis), sgn is the signal of the difference of subsequent stream-flows. In Equations 3 and 4, $\mathrm{E}[\mathrm{S}]$ is the mean of $\mathrm{S}, \operatorname{Var}[\mathrm{S}]$ is the variance of $S$, $p$ is the number of tied groups (sets of data from the sample that have the same value) and $t_{j}$ is the number of data of the $\mathrm{j}$ order tied group. $\mathrm{Z}$ (Eq. 5) represents the test statistic for samples with $n>10$, which approximates to the normal distribution.

$$
\mathrm{S}=\sum_{\mathrm{k}=1}^{\mathrm{n}-1} \sum_{\mathrm{j}=\mathrm{k}+1}^{\mathrm{n}} \operatorname{sgn}\left(\mathrm{x}_{\mathrm{j}}-\mathrm{x}_{\mathrm{k}}\right)
$$




$$
\begin{aligned}
& \operatorname{sgn}(x)=\left\{\begin{array}{rr}
+1, & x>0 \\
0, & x=0 \\
-1, & x<0
\end{array}\right. \\
& E[S]=0 \\
& \operatorname{Var}[S]=\frac{\left\{n(n-1)(2 n+5)-\sum_{j=1}^{p} t_{j}\left(t_{j}-1\right)\left(2 t_{j}+5\right)\right\}}{Z}=\left\{\begin{array}{rr}
\frac{S-1}{[\operatorname{Var}(S)]^{\frac{1}{2}}} \text { if } S>0 \\
\text { if } S=0 \\
\frac{S+1}{[\operatorname{Var}(S)]^{\frac{1}{2}}} \text { if } S<0
\end{array}\right.
\end{aligned}
$$

The Regional Mann-Kendall test (Helsel and Frans 2006) is an adaptation of the Seasonal MannKendall test (Hirsch et al. 1982; Hisrch and Slack, 1984) by the substitution of the seasons in the Seasonal test by places in the Regional test (Helsel and Frans, 2006). The regional test statistic $\left(S_{r}\right)$ is given by the sum of individual statistics, according to Equation 6, in which $\mathrm{m}$ is the number of places in the region and $S_{L}$ is the Mann-Kendall test statistic for the place L. As in the individual Mann-Kendall test, the test statistic variable can be converted to $Z_{r}$ (Eq. 7), when sample size $n>10$, which also approximates to the normal distribution. In this case, the mean of $S_{r}$ is calculated by the Equation 8, and its standard deviation by the Equation 9, been $n_{L}$ the number of data of the $\mathrm{L}$ order place from the $\mathrm{m}$ places of the region.

$$
\begin{aligned}
& \mathrm{S}_{\mathrm{r}}=\sum_{\mathrm{L}=1}^{\mathrm{m}} \mathrm{S}_{\mathrm{L}} \\
& \mathrm{Z}_{\mathrm{r}}=\left\{\begin{array}{c}
\frac{\mathrm{S}_{\mathrm{r}}-1}{\sigma_{\mathrm{S}_{\mathrm{r}}}}, \text { para } \mathrm{S}_{\mathrm{r}}>0 \\
0, \text { para } \mathrm{S}_{\mathrm{r}}=0 \\
\frac{\mathrm{S}_{\mathrm{r}}+1}{\sigma_{\mathrm{S}_{\mathrm{r}}}}, \text { para } \mathrm{S}_{\mathrm{r}}<0
\end{array}\right. \\
& \mu\left(\mathrm{S}_{\mathrm{r}}\right)=0 \\
& \sigma_{\mathrm{S}_{\mathrm{r}}}=\sqrt{\sum_{\mathrm{L}=1}^{\mathrm{m}}\left(\frac{\mathrm{n}_{\mathrm{L}}}{18}\right)\left(\mathrm{n}_{\mathrm{L}}-1\right)\left(2 \mathrm{n}_{\mathrm{L}}+5\right)}
\end{aligned}
$$

A region is as a spatial area with similar physical characteristics, or even various discrete areas with the same physical characteristics (Helsel and Frans 2006). In this work, the SMEPA is considered a well defined region.

The Mann-Kendall test assumes that the data used are independent, meaning that there is no shortterm serial correlation between them (Helsel et al. 2006). Once serial autocorrelation is detected in the series, procedures such as pre-whiten (Bayazit and Onoz 2007) may be used to eliminate it. In this work, the detection of serial autocorrelation was performed by calculating the autocorrelation function $(\mathrm{ACF})$ for the stations series, which were analyzed for the lag 1 and 5\% significance (Burn et al. 2004; Wilson et al. 2010). When autocorrelation was detected, it was removed using the pre-whiten procedure.

The Mann-Kendall and Regional Mann-Kendall Regional tests were performed computationally, using the program developed by United States Geologic Survey (USGS) (Helsel et al. 2006). Besides calculating the test statistics and p-value (analyzed for a significance $\alpha=0.05$ ), the program also calculates the Theil-Sen slope/trend estimator $(\beta)$ and the Kendall $\tau$ coefficient. For the Regional Mann-Kendall test, trend is presented in the form of increase or decrease of the variable per unit of time (in $\mathrm{m}^{3} \cdot \mathrm{s}^{-1}$.year ${ }^{-1}$ for streamflow analysis and $\mathrm{mm}$.year ${ }^{-1}$ for rainfall analysis).

\section{RESULTS AND DISCUSSION}

The results obtained by the application of the described methodology are presented below.

\section{Serial autocorrelation analysis}

Tables 4 and 5 present the autocorrelation coefficients (ACC) of the mean annual streamflow and total annual rainfalls of series used in the study for the different stations and periods.

Table 4 showed that the autocorrelation coefficients of the analyzed stations exceeded the 95\% confidence bounds for the lag 1 during the 1990-1998 period for stations 58211000 and 61250000 , which means that this series presented serial correlation. This series were pre-whitened before the application of Mann-Kendall test. 
Table 4 - Stramflow autocorrelation coefficients for lag 1 and 95\% confidence bounds (CB).

\begin{tabular}{ccrrrr}
\hline Period & Description & $\mathbf{5 8 2 1 1 0 0 0}$ & $\mathbf{5 8 5 3 0 0 0 0}$ & $\mathbf{6 1 0 1 4 0 0 0}$ & $\mathbf{6 1 2 5 0 0 0 0}$ \\
\hline \multirow{2}{*}{$1980-1998$} & ACC lag 1 & $-0.507^{*}$ & 0.1818 & 0.4322 & $0.6500^{*}$ \\
& \pm CB (95\%) & 0.4714 & 0.4714 & 0.4714 & 0.4714 \\
\hline \multirow{2}{*}{$1980-2009$} & ACC lag 1 & - & 0.1303 & 0.2003 & - \\
& \pm CB (95\%) & - & 0.3714 & 0.3714 & - \\
\hline
\end{tabular}

* Indicates lag 1 autocorrelation.

Table 5 - Rainfall autocorrelation coefficients for lag 1 and $95 \%$ confidence bounds (CB).

\begin{tabular}{ccrrrr}
\hline Period & Description & $\mathbf{2 2 4 5 0 1 0}$ & $\mathbf{2 2 4 5 0 8 7}$ & $\mathbf{2 2 4 4 0 6 5}$ & $\mathbf{2 2 4 4 0 3 8}$ \\
\hline \multirow{2}{*}{$1980-1998$} & ACC lag 1 & 0.0549 & -0.2372 & 0.2481 & -0.4243 \\
& \pm CB (95\%) & 0.4714 & 0.4714 & 0.4714 & 0.4714 \\
\hline \multirow{2}{*}{$1980-2009$} & ACC lag 1 & 0.068 & -0.2686 & 0.1851 & -0.3209 \\
& \pm CB (95\%) & 0.3714 & 0.3714 & 0.3714 & 0.3714 \\
\hline
\end{tabular}

* Indicates lag 1 autocorrelation.

\section{Trend analysis}

Based on the p-values from Table 6, it could be concluded that only the station 58530000 presented statistically significant trends in relation to mean annual streamflows for the period 19801998. The negative Mann-Kendall statistics represents reductions of the mean annual streamflow for the period. The rate of these reduction is $0.22 \mathrm{~m}^{3}$.(s.year) $)^{-1}\left(1.8 \%\right.$.year ${ }^{-1}$ of the MSF of the period).

Based on Table 7 results, none of the stations presented statistically significant trends for the period of 1998-2009, although the station 58530000 presented a downward trend in the period of 1980-1998.

Although only station 58530000 presented a significant trend according to the individual tests, based on Table 8 results, the combined results of the SMEPA's watersheds presented a regional statistically significant downward trend of -0.11 $\mathrm{m}^{3}$.(s.year) ${ }^{-1}$.Table 9 presents the results of Regional Mann-Kendall test for the period of 1980-2009.

Table 6 - Mann-Kendall test results for 1980 to 1998 period.

\begin{tabular}{ccccccc}
\hline Station & $\boldsymbol{\tau}$ & $\mathbf{S}$ & $\mathbf{Z}$ & $\mathbf{p}$-value & $\boldsymbol{\beta}$ & Significant trend? $(\boldsymbol{\alpha}=\mathbf{0 , 0 5})$ \\
\hline $\mathbf{5 8 2 1 1 0 0 0}$ & -0.250 & -34 & $-1,359$ & 0.1740 & -0.055 & No \\
$\mathbf{5 8 5 3 0 0 0 0}$ & -0.399 & -61 & $-2,273$ & 0.0230 & -0.219 & Yes \\
$\mathbf{6 1 0 1 4 0 0 0}$ & -0.294 & -45 & $-1,667$ & 0.0956 & -0.148 & No \\
$\mathbf{6 1 2 5 0 0 0 0}$ & -0.265 & -36 & $-1,442$ & 0.1494 & -0.052 & No \\
\hline
\end{tabular}

Table 7 - Mann-Kendall test results for 1980 to 2009 period.

\begin{tabular}{ccccccc}
\hline Station & $\boldsymbol{\tau}$ & $\mathbf{S}$ & $\mathbf{Z}$ & $\mathbf{p}$-value & $\boldsymbol{\beta}$ & Significant trend? $(\boldsymbol{\alpha}=\mathbf{0 , 0 5})$ \\
\hline $\mathbf{5 8 5 3 0 0 0 0}$ & -0.015 & -6 & -0.094 & 0.9253 & -0.004667 & No \\
$\mathbf{6 1 0 1 4 0 0 0}$ & -0.160 & -65 & $-1,201$ & 0.2299 & -0.046120 & No \\
\hline
\end{tabular}

Table 8 - Regional Mann-Kendall test results for 1980 to 1998 period.

\begin{tabular}{ccccccc}
\hline Stations & $\boldsymbol{\tau}$ & $\mathbf{S}$ & $\mathbf{Z}$ & $\mathbf{p}$-value & $\begin{array}{c}\boldsymbol{\Delta} \\
\left.\left[\mathbf{m}^{\mathbf{3}} \text {.(s.year }\right)^{-\mathbf{1}}\right]\end{array}$ & $\begin{array}{c}\text { Significant trend? } \\
(\boldsymbol{\alpha}=\mathbf{0 , 0 5})\end{array}$ \\
\hline $\begin{array}{c}\mathbf{5 8 2 1 1 0 0 0 , 5 8 5 3 0 0 0 0 ,} \\
\mathbf{6 1 0 1 4 0 0 0} \text { and } \mathbf{6 1 2 5 0 0 0 0}\end{array}$ & $-0,304$ & -176 & $-3,450$ & 0,0006 & $-0,1075$ & Yes \\
\hline
\end{tabular}

As shown in Table 9, the individual Mann-Kendall test for the period from 1980 to 2009 showed no statistically significant trends in the regional analysis. Table 10 presents the results of Regional Mann-Kendall test for total annual rainfall, considering the four rainfall stations in both the periods (1980-1998 and 1980-2009).

According to Table 10 results, no statistically significant rainfall trends were detected in SMEPA in both analysis periods. 
Table 9 - Regional Mann-Kendall test results for 1980 to 2009 period.

\begin{tabular}{ccccccc}
\hline Stations & $\tau$ & $\mathbf{S}$ & $\mathbf{Z}$ & $\mathbf{p}$-value & $\left.\boldsymbol{\Delta}\left[\mathbf{m}^{\mathbf{3}} \text {.(s.year }\right)^{-1}\right]$ & Significant trend? $(\boldsymbol{\alpha}=\mathbf{0 , 0 5})$ \\
\hline $\begin{array}{c}\mathbf{5 8 5 3 0 0 0 0} \text { and } \\
\mathbf{6 1 0 1 4 0 0 0}\end{array}$ & $-0,087$ & -71 & $-0,929$ & 0,3531 & $-0,0297$ & No \\
\hline
\end{tabular}

$\underline{\text { Table } 10 \text { - Regional Mann-Kendall test results for total annual rainfall. }}$

\begin{tabular}{ccccccc}
\hline Period & $\boldsymbol{\tau}$ & $\mathbf{S}$ & $\mathbf{Z}$ & $\mathbf{p}$-value & $\boldsymbol{\Delta}\left[\right.$ mm.year $\left.^{-1}\right]$ & Significant trend? $(\boldsymbol{\alpha}=\mathbf{0 , 0 5})$ \\
\hline $\mathbf{1 9 8 0 - 1 9 9 8}$ & $-0,114$ & -70 & $-1,307$ & 0,1913 & $-9,85$ & No \\
$\mathbf{1 9 8 0 - 2 0 0 9}$ & $-0,027$ & -44 & $-0,403$ & 0,6867 & $-1,28$ & No \\
\hline
\end{tabular}

\section{DISCUSSION}

When analyzing a watershed by a systemic approach, streamflow (watershed output) can be represented by a transformation function of precipitation (watershed input) defined by the physical characteristics of the watershed (e.g. relief, pedology, soil use and occupation, presence of hydraulic structures). In other words, streamflow is a response of the interaction between the precipitation and watershed characteristics. Rainfall (in tropical watersheds), in turn, is governed by the atmospheric conditions and their interaction with the surface (which define, for example, the evaporation and evapotranspiration rates). Thus, it is assumed that the mean annual streamflow trends can be attributed to:

(1) changes in the climate/meteorological conditions, resulting in rainfall variability, and/or

(2) changes of the physical characteristics of the watershed.

According to Regional Mann-Kendall test results for rainfall (Table 10), the hypothesis (1) (streamflow trends due to climate variability) should be rejected, which suggests that hypothesis (2) (streamflow trends due to changes in the physical characteristics of the watershed) is the most acceptable to explain the streamflow trends detected in SMEPA. Despite this, it is expected that significant changes in land use and occupation does not occur in environmental protection areas, such as SMEPA. To analyze the detected trends of streamflows during the period 1980-1998, assuming that they were induced by changes in the physical characteristics of the watersheds, it was necessary to consider the dynamic of SMEPA deployment.

The SMEPA was created in 1985 , but its
Consultative Council was created only in 2004 by the Brazilian Institute of Environment Ordinance 49 (IBAMA 2004). However, according to the Brazilian National System of Conservation Units (SNUC), there appears no management plan for SMEPA . The SNUC Parameterized Report (http://sistemas.mma.gov.br/cnuc/index.php?ido=r elatorioparametrizado.exibeRelatorio\&relatorioPa drao $=$ true \&idUc $=11$ ) states that agricultural practices, using traditional soil management techniques, cause environmental impacts in terms of water resources within the SMEPA, reinforcing the validity of hypothesis (2) to explain the streamflow trends recorded for the period of 19801998.

Stations 58211000 and 61250000 have small portions of their drainage areas outside the boundaries of the SMEPA, which, in theory, would make them more susceptible to trends arising from the anthropic actions in their watersheds. The watershed of station 58211000 has a small incremental area outside the SMEPA, in the bottom of Paraíba do Sul River Valley, where agricultural activity (rice farming) occurs upstream and around the station. Station 61250000 has a small incremental area within the urban stretch of Campos do Jordão. Although theoretically more susceptible to hydrological variability due to changes in land use and occupation, these two stations did not present statistically significant trends individually, even in the period of 1980-1998, in which a regional trend was detected. In the case of station 58211000 , the literature and satellite images of the area suggest that the constancy of its mean annual streamflow could be the result of regulation and storage processes occurring in the rice farms. According to LABHID (2002), changes in streamflow of Piagui River (in which station 58211000 is installed) due to water abstraction for rice culture irrigation were 
so intense that have already motivated armed conflicts between the farmers. An intake dam was built upstream station 58211000 by DAEE in the 1970s, to bypass part of Piagui River streamflow to the rice croplands (LABHID 2002). Analyzing the database of grants of water resources use right of DAEE (http://www.aplicacoes.daee.sp.gov.br/ usosrec/daeeusosDpo.asp), the total mean streamflow authorized to be abstracted from the Piagui River for irrigation is about $3.0 \mathrm{~m}^{3} . \mathrm{s}^{-1}$, which represents $57 \%$ of the mean long-term streamflow of the river. Besides the effects of regulation and storage, the polders created for rice production can change the water balance of the watershed, particularly in relation to evaporation and infiltration. The irrigated rice areas around Piagui River increased 14\% between 1988 and 2003, from 2,028 ha to 2,363 ha (Paes Júnior and Simões 2006), corresponding to $13.8 \%$ of the total drainage area of station 58211000. Table 11 presents the results of the Regional Mann-Kendall test for the period 1980-1998, excluding the station 58211000 of the test. The re-test without the station 58211000 aimed to remove the possible interference of streamflow regulation in its watershed over the regional trend analysis of SMEPA.

The results presented in Table 11 show that the regional trend of reduction of mean annual streamflow was maintained after the exclusion of station 58211000, however, with an increase of $12 \%$ in its intensity, from $-0.107 \mathrm{~m}^{3}$.(s.year) ${ }^{-1}$ to $0.120 \mathrm{~m}^{3}$.(s.year) ${ }^{-1}$.

No statistically significant trend was detected for the station 61250000. This result suggested that the urbanization of Campos do Jordão during the period did not result in significant changes in mean annual streamflow of the watershed.

Table 11 - Regional Mann-Kendall test results for 1980 to 1998 period, without station 58211000.

\begin{tabular}{ccccccc}
\hline Stations & $\tau$ & $\mathbf{S}$ & $\mathbf{Z}$ & p-value & $\left.\Delta\left[\mathbf{m}^{\mathbf{3}} \text {.(s.year }\right)^{-1}\right]$ & Significant trend? $(\boldsymbol{\alpha}=\mathbf{0 , 0 5})$ \\
\hline $\begin{array}{c}\mathbf{5 8 5 3 0 0 0 0 , 6 1 0 1 4 0 0 0} \\
\text { and 61250000 }\end{array}$ & $-0,321$ & -142 & $-3,166$ & 0,0015 & $-0,120$ & Yes \\
\hline
\end{tabular}

A third hypothesis to justify the significant trends observed wasthe increased abstraction of water for multiple uses within the SMEPA. Although not expected in an environmental protection area, the implementation chronology of the SMEPA, its current management situation, and the described land use and occupation processes could support this hypothesis. Furthermore, the water resources management legal instruments began to be established in the states of SP, MG and RJ from the 1990s, coinciding with the period during which significant changes were observed in the present study. In this sense, an uncontrolled increase in water abstraction in SMEPA, before the regularization of the multiple uses by the grant of rights could be an explanatory factor of the reduction trends of streamflows during 1980-1998. The overall results of the present work reinforces the environmental and ecological importance of the SMEPA, as changes of mean annual streamflows detected have no association with changes in rainfall, which suggests that land occupation and water resources use changes may be the main drivers of the streamflow trends.

\section{CONCLUSIONS}

According to the Mann-Kendall tests, the mean annual streamflows of the Serra da Mantiqueira Environmental Protection Area did not present statistically significant trends for the period of 1980-2009. Such trends were detected in the subperiod of 1980-1998, when there was a reduction of regional streamflows. This reduction was probably related to human activities in the SMEPA, since no significant rainfall trends were observed in the area.

\section{ACKNOWLEDGEMENTS}

The author thanks the Brazilian Coordenação de Aperfeiçoamento de Pessoal de Nível Superior (CAPES) for the PNPd postdoctoral scholarship.

\section{REFERENCES}

Bates BC, Kundzewicz ZW, Wu S, Palutikof JP. Climate Change and Water. Technical Paper of the Intergovernmental Panel on Climate Change. Geneva: IPCC Secretariat; 2008. 
Bayazit M, Önöz B. To prewhiten or not to prewhiten in trend analysis?. Hydrol Sci J. 2007; 52(4): 611624.

Becker CG, Rodriguez D, Zamudio KR. The Brazilian Adirondacks?. Science. 2013; 340(6131): 428-428.

Brasil. Decreto $n^{\circ} 91.304$ of 3 june 1985. Dispõe sobre a implantação de área de proteção ambiental nos Estados de Minas Gerais, Rio de Janeiro e São Paulo, e dá outras providências. Diário Oficial da União, Brasília (1985 jun. 03); Sec.1:8020.

Brazilian Institute for Environment (IBAMA). Brasil. Portaria no 491.304 of 7 may 2004. Cria o Conselho Consultivo da Área de Proteção Ambiental da Serra da Mantiqueira. Diário Oficial da União, Brasília (2004 mai. 07).

Burn DH, Cunderlik JM, Pietroniro A. Hydrological trends and variability in the Liard River basin. Hydrol Sci J. 2004; 49(1): 53-67.

Harrigan S, Murphy C, Hall J, Wilby RL, Sweeney J. Attribution of detected changes in streamflow using multiple working hypotheses. Hydrol Earth Syst Sci. 2014; 18: 1935-1952.

He B, Miao C, Shi W. Trend, abrupt change, and periodicity of streamflow in the mainstream of Yellow River. Environ Monit Assess. 2013; 185(7): 6187-6199.

Helsel DR, Frans LM. Regional Kendall test for trend. Environ Sci Technol. 2006; 40(13): 4066-4070.

Helsel DR, Mueller DK, Slack JR. Computer program for the Kendall family of trend tests: U.S. Geological Survey Scientific Investigations Report 2005-5275. Reston: USGS; 2006.

Hipel KW, Mcleod AI. Time series modelling of water resources and environmental systems. Amsterdam: Elsevier Science; 1994.
Hirsch, R. M., Slack, J. R. A nonparametric trend test for seasonal data with serial dependence. Water Resour Res. 1984; 20(6): 727-732.

Hirsch RM, Slack JR, Smith RA. Techniques of trend analysis for monthly water quality data. Water Resour Res. 1982; 18(1): 107-121.

Joseph JF, Falcon HE, Sharif HO. Hydrologic trends and correlations in South Texas River basins: 19502009. J Hydrol Eng. 2013; 18(12): 1653-1662.

Paes Júnior N, Simões SJC. Evolução espacial de áreas irrigadas com base em sensoriamento remoto o Médio Vale do Paraíba do Sul, Sudeste do Brasil. Ambiente Água, Taubaté. 2006; 1(1): 72-83.

Kendall MG. Rank correlation methods. 4. ed. Londres: Charles Griffin; 1975.

Laboratório de Hidrologia e Estudos do Meio Ambiente. Síntese do documento Plano de Recursos Hídricos para a fase inicial da cobrança na Bacia do Rio Paraíba do Sul. Rio de Janeiro: UFRJ, COPPE, LABHID; 2002.

Mann HB. Non-parametric test against trend. Econometrica. 1945; 13(3): 245-259.

$\mathrm{Xu} \mathrm{Z}$, Liu Z, Fu G, Chen Y. Trends of major hydroclimatic variables in the Tarim River basin during the past 50 years. J Arid Env. 2010; 74: 256267.

Wilson D, Hisdal H, Lawrance D. Has streamflow changed in the Nordic countries? Recent trends and comparisons to hydrological projections. J Hydrol. 2010; 394: 334-346. 